\title{
OLIGARCHIC "DEMOCRACY"
}

\section{by ELLEN MEIKSINS WOOD}

For sheer bloody-minded greed and unscrupulous acquisitiveness, the Romans had no equal in the ancient world, and they would have had little to learn on that score from modern "possessive individualism." To someone who does not take the predatory impulses of contemporary capitalism and modern imperialism for granted as a universal law of natureand maybe even for those who do- this insatiable rapacity is the most striking thing about the ancient Romans. By the time the republican era drew to a close, giving way to an imperial state (conventionally dated from the foundation of the Principate under Augustus Caesar in 27 B.C.), the Roman ruling class had amassed private fortunes of staggering proportions, by means of exploitation and corruption at home (from their landed estates and urban slum tenements, usury, trading in property, government contracts, etc.) and even more spectacularly by the systematic plunder of their expanding Empire. The administration of the Empire provided the Roman aristocracy with unprecedented opportunities for looting and extortion. To hold proconsular office was a sure means of lining the pocket-and for the most prominent Roman oligarchs to consolidate their personal power by acquiring what increasingly amounted to private armies. "No administration in history," as one distinguished historian of Rome has remarked, "has ever devoted

Ellen Meiksins Wood is author of The Retreat from Class and, most recently, PeasantCitizen and Slave. 
itself so whole-heartedly to fleecing its subjects for the private benefit of its ruling class as Rome of the last age of the Republic." With slaves and peasants creating wealth for landlords, and the urban masses in the huge metropolis of Rome living in appalling, overcrowded, unsanitary, and dangerous slums, the differences of income between rich and poor ranged from a minimum of 1200 to $I$ to a maximum of 20,000 to I (in contrast, for example, to an estimated ratio of several hundred to one in Athens after the Peloponnesian War). ${ }^{2}$

The political expression of this rapacious oligarchy was the republican form of government, dominated by the aristocratic Senate. Resistant to a strong state which would cramp their oligarchic style, the Roman aristocracy governed collectively, with individuals holding office for limited periods and every senator subject to principles of collegiality. There was thus from the beginning a tension at the heart of the Republic. This state, built upon private wealth, was an instrument of individual ambition and acquisition for a ruling class of private proprietors who competed with one another for wealth and power; their class position, however, in the absence of a superior state power, was sustained only by their own fragile collegiality.

This form of state also implied an ambiguous relationship between the aristocracy and the subordinate classes. Like Athens, Rome departed from the pattern which characterized other ancient "high" civilizations where a clear division existed between ruling monarchical states and subject peasant communities. ${ }^{3}$ In Rome, as in Athens, peasants and urban plebeians belonged to the community of citizens; but while a distinctive relationship between landlords and peasants in Athens had given rise to democracy, in Rome a somewhat different balance of class forces produced an aristocratic state whose dominant class was nevertheless obliged to enlist the political and military support of its subordinate fellow-citizens.

The growth of the Empire aggravated the inherent weaknesses of the republican state by enlarging the scope of oligarchic competition and raising the stakes. In the context of an increasingly unruly oligarchy, the vast military apparatus of 
imperial expansion - which, later in the period of Empire, was professionalized and became perhaps the largest military force the world had ever known-was bound to be deployed in the service of personal ambition and intra-oligarchic rivalry. The Empire also placed intolerable strains on the administrative capacities of the Republic and its principle of government by amateurs. It is not surprising that the fabric of republican government gave way under the strain.

The most famous period of Roman history, the time of Julius Caesar and Marcus Tullius Cicero, was the end of the Republic, in which unceasing intra-oligarchic conflict and violence, corruption, and a general breakdown of order spilled over into the vast expanses of the Empire, as ambitious aristocrats brought their proconsular armies into play. The time of troubles was brought to an end and the cohesion and class power of the oligarchy preserved only by the establishment of an imperial state in place of the city-state form of the Republic. If the class interests of the oligarchy had sustained the Republic, the acquisitive and expansionary logic of that same oligarchy drove it beyond the narrow bounds of the republican form.

It is the transitional moment between Republic and Empire that Arthur D. Kahn has taken as his subject in The Education of Julius Caesar: A Biography, A Reconstruction. ${ }^{4}$ This lively and provocative narrative obviously owes much to Kahn's own varied career: from public service to progressive politics and, after experiences with McCarthyism, a new late career as professor of classics. Kahn's detailed narrative paints a vivid picture of oligarchic conflict and corruption during this period: the plots and counterplots, adding up to gang-warfare, of oligarchic factions conspiring to displace one another; the chicanery and bribery of election campaigns. He reveals the extortionate practices of the enormously wealthy Crassus, described by ancient commentators as someone who would readily "cheat and trick and ask and bargain and plunder and snatch ... defraud partners and pillage the treasury" (p. 91), who "[took] bribes for his voice in the Senate, wronging the allies, circumventing weak women with his flatteries and aiding 
base men to cloak their iniquities," and who chased fires (of which there were many in the over-crowded capital) to cheat distraught property-owners out of their properties. He describes the campaign manual produced by Quintus for his brother Cicero's consular election, a manual which could have taught George Bush a thing or two about sleaze-advising the candidate to deride one of his opponents as "born in his father's beggary, bred in his sister's debauchery, grown up in civil slaughter. .." (p. 134). And, on a grander scale, Kahn narrates the maneuvering for political and military position by great commanders like Pompeius and Caesar himself, the climax of which was Caesar's famous crossing of the Rubicon, the "casting of the die" which sealed the fate of the Republic. He represents Caesar as the agent of history, a foresighted aristocrat who perceived that the interests of the oligarchy now lay in reform and especially in the transformation of the Roman Republic into a properly imperial state.

There will be those who object to Kahn's glorification of Caesar, perhaps with some justice. He does go rather too far in depicting this complex figure as motivated unambiguously by sympathy for the common people and a disinterested wish to save his beloved Rome with his prophetic vision of imperial unity. One might have preferred a somewhat less onesided picture which recognized that Caesar's career was not simply a matter of a forward-looking reformer pitted against a corrupt oligarchy. Caesar, after all, was himself the quintessential oligarch, a man of exceptional talent no doubt, and even, in certain respects, a man of principle; but his lifestory was the archetypal career-albeit on a heroic scale, exceptionally successful and also exceptionally violent $\longrightarrow$ of a Roman aristocrat, a warlord who deployed his extraordinary political and military talents, as well as his aristocratic family connections, to consolidate and expand his personal power and wealth. But if Kahn's noble Caesar is just a bit too noble, this picture is less misleading than the conventional romantic version of Roman history, which gives us Caesar the aspiring dictator and enemy of the Republic, finally assassinated by 
patriotic lovers of ancient Roman liberties, often casting Cicero in the role of the pure and selfless defender of classical republican virtues.

Indeed, the very notion of classical republican virtues must be taken with a healthy pinch of salt. Roman history certainly offers models of military virtue, courage, self-sacrificing fortitude, and the pursuit of honor and glory for the self and the Roman people. But these ancient virtues were inseparable from a system of private appropriation and exploitation, the same system that produced the expansionary drive of the Empire. The era of corruption and decline was no less a part of the republican logic than were the legendary virtues of ancient Roman heroes.

The ambiguity of Roman republican virtue is nowhere better illustrated than in the case of Cicero: great orator, champion of liberty and self-appointed guardian of Roman public morals, beloved of Latin teachers everywhere. ${ }^{5}$ Maybe Kahn exaggerates when he paints such an unflattering portrait of Cicero as a hypocritical trimmer, the "new man" from the equestrian order who, lacking an ancient and distinguished noble lineage, always maneuvered to stay on the right side of the conservation oligarchic grandees in order to further his career, a man ready to engage in any "shabby maneuvering" including discovering subversive plots against the state where they did not exist, acting as a kind of ancient Joe McCarthy. But if this is going too far (especially in contrast to the largely uncritical portrait of Caesar), it is a healthy corrective to the standard view of Cicero, defender of republican virtue. Only an expurgated account of Cicero's career can turn him into an attractive figure or disguise the ambiguities in the virtues for which he was a self-appointed spokesman. He was certainly no stranger to the struggles for wealth and power that characterized the Roman oligarchy, and like others he used proconsular office to line his pockets- though perhaps we should marvel at the modesty of the spoils he brought home from his governorship in the province of Cilicia, compared to the fortunes other less virtuous men might have acquired. Or perhaps we should admire his classic Roman stoicism in his capacity as slum 
landlord. Writing to his friend Atticus, Cicero gives a wonderful display of this ancient virtue:

two of my shops have collapsed and the others are showing cracks, so that even the mice have moved elsewhere, to say nothing of the tenants. Other people call this a disaster, I don't call it even a nuisance. Ah Socrates, Socratics, I can never repay you! Heavens above, how utterly trivial such things appear to me! However, there is a building scheme under way, Vestorius advising and instigating, which will turn this loss into a source of profit. ${ }^{6}$

And a few days later: "The collapse of the building has not lowered the returns, indeed I rather think it may actually have increased them." This passage conveys something of the flavor of late republican Rome and tells us at least as much about its characteristic values as do Cicero's oratorical laments at the moral decline of his contemporaries. Although this story does not appear in Kahn's biography of Caesar, his book provides ample evidence to illustrate the character of the oligarchy. The virtue of this biography is that it reveals the dynamics of the Republic by presenting a vivid portrait of the oligarchy in action.

Kahn's vision of Rome is colored by his view of U.S. history and the current state of U.S. politics, as he makes clear in his preface. The thinly disguised parallels occasionally lead to exaggerations and distortions-like Cicero as McCarthy, or perhaps Caesar as Roosevelt, seeking to save the Roman aristocracy from itself through popular reform just as F.D.R. saved capitalism with the New Deal. Given the vast differences in time and social form between these two cases, such historical analogies, explicit or implicit, lead Kahn onto dangerous ground. Nevertheless, there are some instructive connections to be made. When Kahn, writing about the Roman oligarchy's opposition to reform, remarks that "the thoughts and opinions of Cato's clique were 'good Roman thoughts and opinions,' the contrary were at best outlandish, at worst 'subversive,' and fundamental political and social questions were rarely posed in the elections (that epitome of Roman oligarchic 'democracy'),' (p.308) there can be little doubt that he has the United States in 
mind. And indeed the concept of "oligarchic democracy" conveys a truth about U.S. politics every bit as telling as its application to ancient Rome. It is no accident that the Founding Fathers of the U.S. Republic looked to Roman models for inspiration in making the Federalist case, adopting Roman names as pseudonyms and conceiving of themselves as latterday Catos, forming a natural aristocracy of republican virtue. (Americans today still have a representative body called the Senate, and their republic is still watched over by the Roman eagle.) Faced with the distasteful specter of democracy, they sought ways to redefine that unpalatable concept to accommodate aristocratic rule, producing a hybrid, "representative democracy," which was clearly meant to achieve an effect similar to the ancient Roman idea of the "mixed constitution," in fact, an "oligarchic "democracy.",

Perhaps, too, there is something worth considering in Kahn's analogy between the corruption of the ancient Roman republican ideal and the degeneration of U.S. politics from the founding days to the era of Ronald Reagan-not, however, simply in the sense that there has been a decline from virtue to corruption, but rather in the sense that the "corruption" was already implicit in the foundation. Just as the inherent logic of the Roman oligarchy produced the decline of the Republic, there is no need to be surprised at the degeneration of a U.S. "democracy" originally conceived and constructed as a contradiction in terms, as an "oligarchic democracy" in which an aristocracy of property-holders was to govern a popular electorate. There is really nothing to wonder at, for example, if the Federalist ideal of an aristocracy combining propertied wealth with republican virtue gave way to the unadulterated rule of wealth alone, in which money speaks louder than competence, let alone "virtue," and political substance is banished from public debate as the fundamental social issues which divide a class society are submerged in electoral trivia.

Both the U.S. and Roman republics involved a curious and contradictory nexus between property and popular politics (summed up in the famous Roman formula SPQR, "the Senate and the Roman People") with a propertied oligarchy which 
required the support of a populace whose fundamental interests were often very different. In both cases, this contradictory arrangement eventually produced a degenerate and vacuous political process. The capitalist system, however, has allowed the U.S. oligarchy a certain distance from politics and the state a certain "relative autonomy." While it is virtually impossible in the U.S. "democracy" to hold major political office without substantial wealth, it is of course possible, indeed customary, for capitalists to acquire substantial wealth without direct possession of state power. But Roman society was not capitalist, and the oligarchy could not so readily distance itself from the direct exercise of political power. They not only controlled the republican state. They were the state, embodied in the Senate.

Yet this unity of state and class took a very different form in Rome than in other advanced civilizations of the ancient world-and here we may find some explanation for the extreme rapacity of the Romans and the powerful force of their expansionary drive. The Roman preoccupation with property, the monumental scale of its land-grabbing project both in the concentration of oligarchic property at home and in imperial expansion, was unprecedented and unequalled in the ancient world. It reflected a distinctive system of social relations and class reproduction. In other ancient civilizations where centralized states ruled subject peasant communities, access to the surplus labor of others was typically achieved by direct possession of the state. This did not necessarily preclude private possession of land, either for those who acquired it as a perquisite of office or for peasant smallholders; but access to substantial wealth-that is, to the surplus labor of others on a large scale-was not a function of property as such but rather a function of state power. Variations on this basic theme have been widespread and persistent, even in times and places where private property has been well established. For example, late imperial China had a highly developed system of private property, with free buying and selling of land. At the same time, great wealth and power resided elsewhere, not in the land but in the imperial state, in an elite at the top of which stood the 
court and imperial officialdom. This imperial state encouraged and expanded the smallholder economy, while centralizing administrative power by coopting large proprietors into the state. ${ }^{7}$

The contrast with Rome is striking. As in other precapitalist societies, juridical status and political power remained a critical factor in Roman relations of exploitation. But in the absence of a centralized appropriating state superimposed on subject producing communities, and in the absence of a clear monopoly of juridical privilege and political power for the ruling class, private property had become an end in itself in unprecedented ways. Land ownership had become the major condition for surplus extraction, and there had developed a compelling pressure to acquire land, even to dispossess smallholders. Since the citizenship of peasants precluded their juridical dependence, their exploitation-as tenants or casual laborers-depended on their economic vulnerability. Alternately, they could be replaced by slaves as a labor force on large estates, so that in the last century of the Republic in Roman Italy-where agricultural slavery had greater importance than in other parts of the Empire, such as North Africa or the East-one-third of the population consisted of slaves. The collective power of the aristocracy was sufficient (unlike, for example, in ancient Athens) to achieve an unprecedented concentration of land in the hands of the oligarchy. The principal career for the Roman ruling class was the acquisition and management of property. Public office was a moment in that career. Even service in the provinces was a way of looting subject populations to obtain the means of investing in property. When these distinctive property relations outgrew the Republican state, they produced a new imperial system, an "undergoverned" Empire which administered its far-flung territories through a network of self-governing cities (often newly founded and in predominantly rural areas) which amounted to a massive class federation of local aristocracies. ${ }^{8}$ In the process, the juridical and political status of the peasantry declined. This imperial system, with its diffuse administration, enhanced and extended the power of private property. 
So the Roman Republic-whose declining years Arthur Kahn has brought so vividly to life--established the rule of property as never before, and the Empire pushed forward the frontiers of that regime. The rest, as they say, is history.

\section{NOTES}

1. Ernst Badian, Roman Imperialism in the Late Republic 2nd ed. (Oxlord: Basil Blackwell, 1968), p.87.

2. See Neal Wood, Cicero's Social and Political Thought (Berkeley: University of California Press, 1988), pp. 33, 223 n. 28, and Richard Duncan-Jones, The Economy of the Roman Empire: Quantitative Studies 2nd ed. (Cambridgc: Cambridge University Press, 1982).

3. I have discussed these distinctive social relations in the case of ancient Athens in Peasant-Citizen and Slave: The Foundations of Atherian Democracy (London: Verso Books, 1988).

4. Arthur D. Kahn, The Education of Julius Caesar: A Biography, A Reconstruction (New York: Schocken Books, 1986).

5. See N. Wood, Cicero's Social and Political Thought, for a detailed discussion of his life and career.

6. Quoted in N. Wood, pp. 110-11.

7. See Philip Huang, The Peasant Economy and Social Change in North China (Palo Alto: Stanford University Press, 1985).

8. The Roman Empire has been described as "government without bureaucracy," made possible by this municipal system. See Peter Garnsey and Richard Saller, The Roman Empire: Economy, Society and Culture (Jondon: Duckworth, 1987), p. 26. The imperial state did, of course, have its share of centrally appointed officials; but, as Garnsey and Saller remark, the Empire "remained undergoverned, certainly by comparison with the Chinese Empire, which employed, proportionately, perhaps twenty times the number of functionaries" (p. 20). Although imperial office remained a road to fame and fortune, aristocrats were not always keen to take it. Commenting on the aristocratic desire for cum dignilate otium (leisure with dignity), Chester Starr in his The Roman Empire, 27 B.C. 10 A.D. 476: A Study in Survival (New York: Oxford University Press, 1982) has explained the principal motivation of the aristocracy for seeking release from public duties: "I 'heir prinary function and activity after all was the supcrvision and maintenance of their wealth" (p.63). 